Int.J. Hum. Soc. Dev. Res.

ISSN(P):2521-1439; ISSN(E):2523-4331

Volume 2, № 2, 2018. 19-28

DOI: $10.30546 / 2523-4331.2018 .2 .2 .19$

\title{
Globalization and Woman Migration: Changing Gender Roles
}

\section{Kifayat AGHAYEVA}

Azerbaijan University of Languages, Baku, Azerbaijan

(C) The Author(s) 2018

\begin{abstract}
Globalization, often perceived as a threat to migrant workers and the realization of their rights. Trafficking in women and children for sexual purposes has become a very lucrative business, third in size after the trans-national illegal trade in arms and drugs. Rising unemployment and partial unemployment, the reduction of social services, automation of labor, poverty, inequality and violence against women compel them to seek new survival strategies. Despite the migrant women face the discrimination, multiple problems and the adverse conditions, they try their chances to improve their positions and achieve economic independence and personal growth.
\end{abstract}

(C)2018. All rights reserved.

\section{ARTICLE HISTORY}

Received: $21 / 01 / 2018$

Accepted: 07/07/2018

Published online: 05/10/2018

\section{KEYWORDS}

Globalization, woman migration, gender stereotypes, gender discrimination 


\section{Introduction}

Mankind has witnessed an enormous economic changes that have occurred over the past three decades, nominated by the growing flows of goods and services, technology and information. These changes have transformed the way the internal and global markets and institutions function - and thus, changed the economic landscape for individuals, families, businesses and governments. The world is becoming more and more integrated. What started with a more open trade translating into growing global economic integration and interdependence, as the transnational movement of people and capital and accelerate the information on it becomes more affordable. Technological developments are rapidly changing the way people learn, work, and communicate. And the world's population is concentrated in large and medium cities. The relation between globalization promoting policies, economic growth, inequality and poverty is heavily debated and remains unsettled. One of the central aspects in the debate concerns the possible gendered dimension of the structural changes. The question of concern here is if and how it can be claimed that globalization induced gains and losses are unevenly distributed between the sexes. Are there reasons to believe that the effects of globalization do not spread evenly among males and females and that this has devastating effects on women in developing countries?

Most research on globalization, gender and migration- whether concerned with internal, international or transnational mobility- has focused on women migrants' changing roles within the family, the household, and the labor market, without paying a great deal of attention to the roles of states. The exceptions have tended to view the State primarily as a policy-making set of institutions that generates the legal regulations that structure citizenship, immigration, childcare, and work (Silvey, 2004, 245-264).

Globalization is generally understood as resulting in greater economic interdependence among countries through international trade, capital flows and international production. Both technological and institutional factors are stressed. On the one hand, globalization has been enabled by new information and communication technologies while on the other hand, globalization has been enabled by free trade and finance-promoting public policy, which convert into reality the possibilities opened by technological innovation.

Globalization encompasses the dynamic processes of international trade and finance that interconnect and increasingly integrate national economies. These global processes have an impact on local labour markets - on employment structures and relationships, wages and working conditions, opportunities for 
women and men and their labor force participation. Globalization has given countries access to a bigger workforce across the world.(Dejardin, Amelita King, 1).

Under contemporary globalization, international labour mobility has increased, while levels of exploitation and deregulation have accelerated. Lack of legal protection for migrant workers heightens their attractiveness as instruments of "maintaining competitiveness" because they are obliged to work in situations where decent work conditions are not enforced. Irregular migrants are especially vulnerable because the threat of apprehension and deportation thwarts unionizing and exposure of dangerous working conditions.

Migration is also about the results of brutal injustice, oppression and warfare. It is the consequence of sustaining dictatorships, of military interventions, as well as the absence of decent work in countries with growing youthful populations where jobs and means to survival are not growing. Migration and trafficking are two different interrelated phenomena. Migration is a broad general concept and trafficking is only a subset or category of the broader conception. Migration is the movement of people from one place to another (in case of international migration one country to another) in order to take up employment or establish residence. International migration (i.e., migration across borders) in particular is a complex and multidimensional phenomenon. The dynamics of international migration is often explained or measures in relation to (either alone or in combination) citizenship, residence, time or duration of stay, purpose of stay, or place or birth. On the other hand, trafficking in persons as a subset of migration is the movement (either internally or internationally) of a person under a situation of deceit, force, threat, debt bondage, etc., involving exploitation and violation of human rights. Trafficking in persons therefore, results in abusive exploitation and human rights violations. Studies suggest that a person by placing himself/herself in the hands of traffickers loses control of his/her fate and freedom and ends up in "harm" situation (Beeks, Karen and Delila Amir, 2006 ,6).

The feminization of international labor migration, together with the fact that most job opportunities for women migrants is in unregulated sectors (domestic work, sex industry) and the existence of sex-disaggregated labor markets contribute to the increase of discriminative labor markets in countries of destination. In addition, women have less access to information on migration/job opportunities, recruitment channels, and often have less preparation than men to cope with the working and living conditions in the countries of destination.

\section{Women and Migration}

Yet, understanding gender is critical in the migration context because migration theory has traditionally emphasized the causes of international migration 
over questions of who migrates, it has often failed to adequately address genderspecific migration experiences. The history of migration is as old as the history of humanity. Since the very beginnings, humans have migrated to build a new, more hopeful existence somewhere else. Today migrants often break away from their home countries as a consequence of warfare, political repression, or severe poverty. Stephen Castles and Mark J. Miller write, "Migration has become a private solution to a public problem." .Migrant labor is also of course associated with a myriad of other problems to which such workers are subjected (Isaksen,Lise Uma Arlie Dave and Hochschild ,65).

The astonishingly high number of women migrating is a new global trend. In the past it was mainly men who went to countries far away; women came as followers. In the last twenty years, however, this has changed so much that today over half of all migrants are women. Furthermore, female migrants have often become the main or single wage earners of their families. Saskia Sassen calls this the "feminization of survival" - societies, governments, and states more and more depend on the work of women in the labor force. Thus the necessary conditions of work and survival fall increasingly on the shoulders of low-waged, deprived, and exploited migrant women (Sassen Saskia ,103).

Gender analysis of current international labor flows, reveal that migration is no longer male-dominated, that women now are migrating independently in search of paid work (as opposed to before as wives accompanying their partners), and that international migration is increasingly becoming feminized.

The main standards protecting migrant workers come from the United Nations agency devoted to labor issues, the International Labor Organization (ILO). It also imposes an obligation on states "to respect the basic human rights of all migrant workers," confirming its applicability to irregular migrant workers. A report from the International Labor Organization (1996), states that Asian women constitute the fastest growing component of international migrant labor. Women constituted half of all cross border migrants and $48 \%$ of intra-regional migrants in 1990 (6).

A central feature of globalization is the increased mobility of people across borders. A feminist perspective of migration reveals that gender roles have limited women's ability to search for better jobs elsewhere. It is therefore, argued that the study of migration must take into account not only the ones that migrate but also the ones who stay behind. Recently, however, the gender focus of migration has shifted from the women left behind to women who migrate themselves.

Migration is perceived by both men and women as a means to improve their living situation and increase their share in development. Poverty and lack of opportunities represent the major factors leading men and women to move away 
from their national border. Female emigration is spurred in part by a large wage differential between sending and receiving countries, and the increasing burden placed on women by rising male unemployment at home, as well as by the reduction in demand for male labor in receiving countries due to economic slowdowns, which cause demand to shift to services that usually employ female labor( Beeks, Karen and Delila Amir, 21-22).

According to the authors the feminization of international labor migration is a global trend. The percentage of women in the migrant population (both permanent and temporary migrants) has been increasing in the postwar period, and at present they comprise the majority of international migrants. Referring to Zlotnik, the authors claim that between 1965 and 1990, the number of female migrants around the world increased by 63 percent-from 35 million to 57 million, an increase of 8 percent higher than that of male migrants and in the US, 53.3 percent of newly admitted were women in 1998.

It is now quite evident that women and men experience migration differently, in complex ways not even captured by the term 'feminization of migration'. Gender differentials need to be set in conjunction with national ethnic, skill level and legal status differentials. What the gender focus provides is an emphasis on the broad social factors influencing women and men's roles and their access to resources in the migration process. While much of the literature on the migration-development nexus focuses on the economic aspects-such as remittances- a gendered perspective directs us to the crucial dimensions and often buried considerations of equality (Ronaldo Munck, 14-15).

Women migrant workers often take jobs in unregulated low-skilled sectors, such as domestic work, childcare, elder care, and commercial sex work. Furthermore, this employment tends to be irregular, unprotected by labor legislation and, often in the case of sex work, facilitated by criminal trafficking networks.

\section{Sex Industry in the World}

Sex tourism is an industry worth billions of dollars, it is estimated that millions of sex workers participating in the world, and this practice may be legal or illegal, depending on the regional laws, whether consensual activity, as well as whether children or trafficking of sex involved. Many countries have become synonymous with sex tourism, whether legal or illegal, and are travel destinations purely for that industry. Migrating women are in a paradoxical situation. On the one hand, their home countries praise them as "heroes" for bringing in remittances and contributing to development and growth. Their husbands and families celebrate them, as they now can afford to live better than ever before (good and healthy food, 
private schools, toys, better houses, etc.). Their employers in the rich North sometimes esteem them, as they acknowledge the increased need for care work. On the other hand, the same women migrants are being criticized and condemned. Many times, their children express disapproval and negative feelings towards their mothers. They keep asking themselves - even years after the migration process has ended and the family is reunited again - whether their mothers really had to "go," why their mothers left them, whether there were alternatives to leaving children behind. Neighbors criticize migrant women, especially the more wealth the migrating women's families acquire, for how "materialistic" those departing women are. After all, they sometimes surreptitiously say, those women were able to leave children and husbands behind just to make money. And very often these are exactly the same thoughts and beliefs that migrating women they have. Thus, women migrants have and face constant self-reflection and self-criticism (Isaksen Lise Uma Arlie Dave and Hochschild, 65-66).

Trafficking in women and children for sexual purposes has in this context become a very lucrative business, third in size after the trans-national illegal trade in arms and drugs. Of these three items, human smuggling brings in far more cash. Drugs and guns can only be sold once. Women and girls can be sold again and again. In many cases, smugglers don't even have to pay for the women and children. There isn't one law or one program to help you escape from that life. Recruiters attract women who are poor and uneducated. They don't need to beat you to make you vulnerable. Poverty does that. The sexual exploitation of women and children and the trafficking of women for purposes of prostitution have existed for all of recorded history, but the escalation and "industrialization" of sexual exploitation are less than a few decades old. The sex industry is the collection of legal and illegal, single and multi-party operations that profit from the selling of women and children through trafficking, organized prostitution and/or pornography ( Cook, 4).

It is believed that the global sex trade constitutes a substantial part of worldwide irregular migration and labor migration. Women and children are increasingly becoming commodities to be bought, sold, and consumed by organized crime rings, tourists, military personnel, and men seeking sexual entertainment or non-threatening marriage partners. Through financial and technological interdependence, the sex industry and the Internet industry have become partners in the global sexual exploitation of women and children. Those with power are using new information technologies to expand their capacity to exploit women and girls throughout the world (Hughes, 1).

The majority of victims are often kept in squalid conditions in a state of virtual house arrest and transported to and from work only. Even when women have relative freedom of movement, their illegal immigration status, inability to 
speak the local language, lack of documents and fear of being arrested, mistreated, and deported keeps them from seeking help from the local law enforcement authorities. For example, IOM (International Organization for Migration) study of trafficking from Azerbaijan reports that, "With one exception, none of the victims have tried to seek assistance from authorities, either in the country to which s/he was trafficked or upon his/her repatriation to Azerbaijan. The primary reason was for that is a lack of trust in law enforcement agencies." (Beeks,Karen and Delila Amir, 69).

Hughes (2000: page) takes a broad look at the links between globalization and commercial-sexual exploitation of women and children, and argues that new technologies, global tourism and globalized crime, have given the sex industry new means of exploiting, marketing and delivering women and children as commodities to male buyers. In regard to the relation between sex industry and the Internet industry, it is argued that the Internet industry is heavily dependent on the sex industry, thrives on it and looks to it for innovation. Four million people, mostly women and girls are reported to be trafficked each year. Many become literally enslaved in the sex industry (Hughes, 70).

It is widely assumed that women and girls enjoy being in prostitution and making pornography., while research findings reveal that women and girls are often tricked and coerced into the sex industry. The United Nations estimates that there are 200 million people around the world forced to live as sexual or economic slaves (Director General of the United Nations Bureau, Vienna, Associated Foreign Press, Nov. 13, 1997.). Few women choose to be in the sex industry. If any choice is involved it is usually the last choice, when no other options are available. Each year, hundreds of Ukrainian women are trafficked into the United States. Most of the women believe they will be employed as waitresses or nannies, only to be forced into the sex industry using debt bondage once they arrived. In a survey of Ukrainian women, zero percent responded that a job in the sex industry was an "acceptable job abroad" (International Organization for Migration, Information Campaign Against Trafficking in Women from Ukraine, Research Report. Int. Organization for Migration, July 1998). In a research study from San Francisco, 88 percent of women in prostitution said they wanted to get out of prostitution, 73 percent said they needed job training, and 67 percent said they needed drug and alcohol treatment (Hotaling, 243). Internationally, 92 percent of women in prostitution report that they wanted to leave prostitution (Farley, 405). These findings reveal the harm done to women in the sex industry and their desire not to be in the sex industry.

\section{Hope or False Dawn?}

Majority of men still take advantage and benefit from the overall subordination of women. This is true also for the Scandinavian countries, which are 
supposed to be the most advanced concerning 'equal opportunities' between men and women (Peace, Bob and Keith Pringle, 146).

Migrant women are often stigmatized for not sticking to the "traditional" gender role assigned to them by a patriarchal culture. They are perceived as having abandoned their families and children for money at the very same time that these economies are strongly dependent upon the remittances these women provide.

Studies reveal that migrants' children are ill more often than other children; they experience resentment, bewilderment, and indifference more than their friends, who live with their mothers. Children of migrant women grew up without their mothers at their sides. The consequences of long separation periods, especially in very young ages, can be devastating. Another negative aspect is the fact that now that mother-child/children relations cannot be based upon direct care, they alter into "care through money." Although mothers make huge sacrifices for their children, trust in mother-child relations erodes and children frequently have doubts about why their mothers had gone.

Migrant workers, and in particular certain vulnerable categories, such as women domestic workers and temporary and irregular labor migrants, continue to suffer abuses and malpractices at the hands of employers, government officials and the general population in receiving countries. This persists despite standards that have been painstakingly devised to enable them to lead a dignified existence when resident and employed abroad (Cholewinski, 10).

Countries that supply the women are complicit in this trade because women who leave will send much of the money they earn to their families back home. At the same time, the countries on the receiving end look the other way because these foreign females often feed a booming and profitable sex tourism industry.The following steps might be put in place in the "sending" countries to help alleviate the problem. They should foster creation of job opportunities for young women; improve law enforcement efforts to prevent and punish trafficking of women; crack down on official complicity in trafficking of women (including stricter control over issuing passports), and combat corruption which fuels organized crime through in the following ways:

- $\quad$ Carry out information campaigns on media and TV about the nature, realities, and risks of lucrative job offers;

- $\quad$ Provide legal, medical and psychological assistance to victims of trafficking; and

- $\quad$ Guarantee safety of victims who testify against the traffickers through witness protection programs. 
The "Receiving" countries, on their part should consider the following actions:

- Amend laws, including immigration law, to exempt victims of trafficking and/or servitude from being these practices. Deportation may be appropriate, but punitive measures, including detention, should be waved;

- Prosecute traffickers and enable victims to bring lawsuits against traffickers by granting temporary residence permits for the duration of the case;

- Impose tougher penalties for trafficking. The United States has already been taking such measures with the adoption of the Trafficking Victims Protection Act of 2000 ;

- Protect safety of victims of trafficking through strong witness protection programs;

- Ensure that victims of trafficking have access to essential social services, including shelter and medical care; and

- Distribute information brochures at the receiving countries' embassies abroad with each visa issued to a woman on the realities and risks of being trafficked and what to do if she found herself trafficked and abused abroad (Beeks, Karen and Delila Amir, 70).

When women migrate from the poorer countries they deprive their own children and elderly parents of the care, love and affection they require and seek, creating a care deficit in their home countries, whereas a care surplus accumulates in wealthier countries (Isaksen, Lise Uma Arlie Dave and Hochschild, 66).

Globalization, often perceived as a threat to migrant workers and the realization of their rights, has also played a role in bringing together diverse and geographically distant voices to their defense, and may yet help bring about important changes at the national and international levels that will ultimately benefit migrant workers. Protection of migrant women is linked to issues of safety and control, and is used to legitimize restriction on migration.

\section{Disclosure statement}

No potential conflict of interest was reported by the author.

\section{Contact Information}

E-mail: kifayat1955@mail.ru 


\section{References and notes:}

Chopra, S. \& Meindl, P. (2007). Supply Chain Management: Strategy, Planning, and Operation, New Jersey, Pearson Prentice Hall.

Christensen, C.M. (2000., European Journal of Purchasing \& Supply Management (6)2, pp.105-116.

Cooper, M.C.,Lambert, D.M. \& Pagh, J.D. (1997). Supply Chain Management: More Than a ew Name for Logistics, The International Journal of Logistics Management, (8)pp. 11-14

Devaraj, S., Krajewski, L., Wei, J.C. (2007). Impact of eBusiness Technologies on Operational Performance: The Role of Production Information Integration in the Supply Chain, Journal of Operations Management, 25, pp.12-29.

Ejupi, V., Siljanovska, L., \& Iseni, A. (2014). The mass media and persuasion. European Scientific Journal, ESJ, 10(14).

Fox, S. (1999), Digital Market, Inc. Stanford Global Supply Chain Management Forum Case, SGSCMF-005-1999.

Grant, R.M. (1996), Toward a knowledge-based theory of the firm, Strategic Management Journal, First published: Winter 1996 https://doi.org/10.1002/smj.4250171110

Mohr, J.\& Nevin, J. (1990). Communication Strategies in Marketing Channels: A Theoretical Perspective, Journal of Marketing,54,pp. 36-51.

Muffatto, M.\&Payaro, A. (2004). Integration of Web-based Procurement and Fulfillment: A Comparison of Case Studies, International Journal of Information Management, 24, pp.296-310.

Rovena, V. A. T. A., Iseni, A. (2016). Elementët e ngjashmërisë dhe intonacionit narrativ midis Kutelit, Turgenievit dhe Gogolit

Phan, D.D. (2003). E-Business Development for Competitive Advantages: A Case Study, Information \& Management, 40, pp.582-600.

Simchi-Levi, D., Kaminsky, P.\& Simchi-Levi, E. (2002).Designing and Managing the Supply Chain, New York, McGraw-Hill.

Stock, J.R., Lambert, D.M. (2001).Strategic Logistics Management. 4th Edition, New York, McGraw Hill

Şahin, A. \&Demir, M.H. (2003), The Effects of Developments in Information Technologies on Logistics Management: A Theoretical Analysis of Supply Chain Orientation, Süleyman Demirel University Faculty of economics and administrative sciences Journal, (8) 3,pp. 31-40

Yurt, Ö. (2004), Turkey factor- Confidence in Logistics Outsourcing Practice, (Unpublished master's thesis). Ankara University / Institute of Social Sciences, Ankara.

Vata, R., \& Iseni, A. (2016). Elementet folklorike të Mitrush Kuteli dhe Nikolaj Gogoli si formë interteksti. ANGLISTICUM. Journal of the Association for Anglo-American Studies, 2(5),pp. 118-123. 